\title{
Radioisotope Distribution Program Progress Report for September 1977
}

\author{
E. Lamb
}




\section{DISCLAIMER}

This report was prepared as an account of work sponsored by an agency of the United States Government. Neither the United States Government nor any agency Thereof, nor any of their employees, makes any warranty, express or implied, or assumes any legal liability or responsibility for the accuracy, completeness, or usefulness of any information, apparatus, product, or process disclosed, or represents that its use would not infringe privately owned rights. Reference herein to any specific commercial product, process, or service by trade name, trademark, manufacturer, or otherwise does not necessarily constitute or imply its endorsement, recommendation, or favoring by the United States Government or any agency thereof. The views and opinions of authors expressed herein do not necessarily state or reflect those of the United States Government or any agency thereof. 


\section{DISCLAIMER}

Portions of this document may be illegible in electronic image products. Images are produced from the best available original document. 
Printed in the United States of America. Available from National Technical Information Service

U.S. Department of Commerce

5285 Port Royal Road, Springfield, Virginia 22161

Price: Printed Copy $\$ 4.00 ;$ Microfiche $\$ 3.00$

This report was prepared as an account of work sponsored by an agency of the United States Government. Neither the United States Government nor any agency thereof, nor any of their employees, contractors, subcontractors, or their employees, makes any warranty, express or implied, nor assumes any legal liability or responsibility for any third party's use or the results of such use of any information, apparatus, product or process disclosed in this report, nor represents that its use by such third party would not infringe privately owned rights. 
Contract No. W-7405-eng-26

OPERATIONS DIVISION

\section{E. Lamb}

Work Sponsored by

DOE Division of Biomedical and.

Environmental Research

NOTICE This documerit contalns information of a preliminary nature and was prepared primarily for internal use at the Oak Ridge National Laboratory. It is subject to revision or correction and therefore does not represent a final report.

OAK RIDGE NATIONAL LABORATORY

Oak Ridge, Tennessee 37830 operated by UNION CARBIDE CORPORATION

for the

DEPARTMENT OR ENERCY OF WTA DOTU:

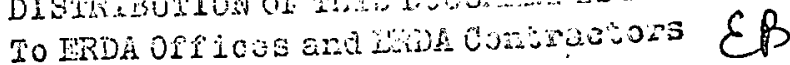




\section{THIS PAGE}

\section{WAS INTENTIONALLY LEFT BLANK}


CONTENTS

Page

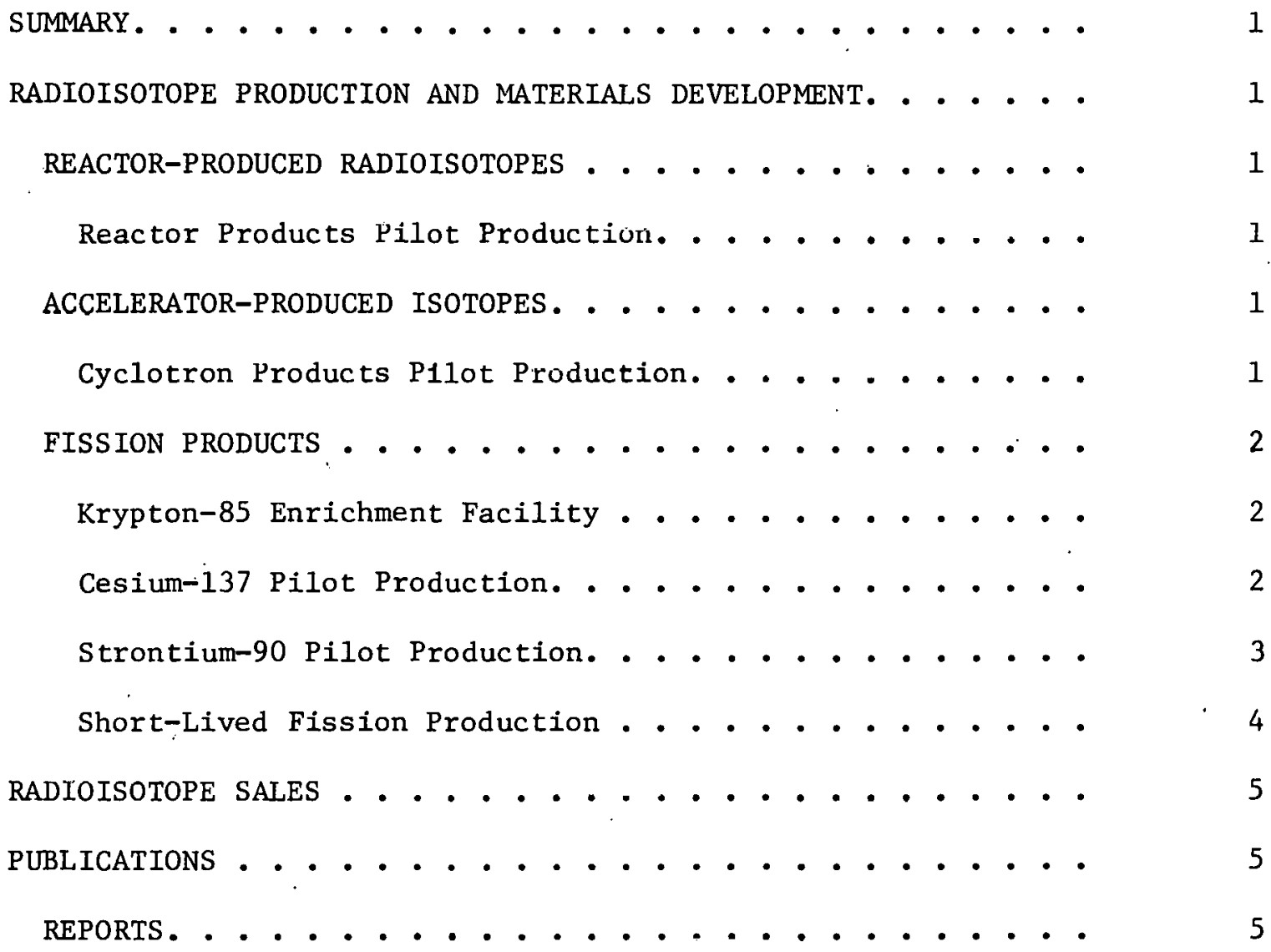


RADIOISOTOPE DISTRIBUTION PROGRAM

PROGRESS REPORT FOR SEPTEMBER 1977

$$
\text { E. Lamb }
$$

SUMMARY

Information is reported on new production, inventory status, operational problems, and radioisotope sales.

RADIOISOTOPE PRODUCTION AND MATERIALS DEVELOPMENT

REACTOR-PRODUCED RADIOISOTOPES

Reactor Products Pilot Production (R. W. Schaich)

(Production and Inventory Accounts)

$\frac{\text { Processed Units }}{\text { Radioisotope Amount (mCi) }}$

Calcium-47

35

ACCELERATOR-PRODUCED ISOTOPES

Cyclotron Products Pilot Production (M. R. Skidmore)

(Production and Inventory Accounts)

September 1977 ORNL 86-Inch Cyclotron runs for ORNL and non-ORNL programs are given in Table 1.

Table 1. Cyclotron Irradiations and Runs for September 1977

\begin{tabular}{|c|c|c|c|c|c|c|c|}
\hline Date & & Customer & & Product. & Target & $\begin{array}{c}\text { Total Time } \\
\text { (hr:min) }\end{array}$ & $\begin{array}{c}\text { Total } \\
\text { Charges }\end{array}$ \\
\hline \multicolumn{8}{|c|}{ ORNL Programs } \\
\hline $\begin{array}{l}9-6-77 \\
9-21-77 \\
9-23-77\end{array}$ & $\begin{array}{l}\text { ORAU } \\
\text { ORAU } \\
\text { ORAU }\end{array}$ & & & $\begin{array}{l}\text { Carbon-11 } \\
\text { Carbon-11 } \\
\text { Carbon-11 }\end{array}$ & $\begin{array}{l}\text { Boron Oxide } \\
\text { Boron Oxide } \\
\text { Boron Oxide }\end{array}$ & $\begin{array}{l}5: 45 \\
4: 30 \\
5: 30 \\
\end{array}$ & $\begin{array}{l}688 \\
543 \\
659 \\
\end{array}$ \\
\hline \multicolumn{8}{|c|}{ Non-ORNL Programs } \\
\hline $\begin{array}{l}9-1-77 \\
9-9-77 \\
9-14-77 \\
9-20-77 \\
9-26-77\end{array}$ & $\begin{array}{l}\text { New } \\
\text { New } \\
\text { New } \\
\text { New } \\
\text { New }\end{array}$ & $\begin{array}{l}\text { England } \\
\text { England } \\
\text { England } \\
\text { England } \\
\text { England }\end{array}$ & $\begin{array}{l}\text { Nuclear } \\
\text { Nuclear } \\
\text { Nuclear } \\
\text { Nuclear } \\
\text { Nuclear }\end{array}$ & $\begin{array}{l}\text { Cobalt }-57 \\
\text { Cobalt-57 } \\
\text { Cobalt }-57 \\
\text { Gallium-67 } \\
\text { Gallium-67 }\end{array}$ & $\begin{array}{l}\text { Nicke1-58 } \\
\text { Nicke1-58 } \\
\text { Nicke1-58 } \\
\text { Zinc-68 } \\
\text { Zinc-68 }\end{array}$ & $\begin{array}{l}51: 15 \\
51: 15 \\
51: 15 \\
57: 15 \\
47: 15 \\
\end{array}$ & $\begin{array}{r}\$ 8,784 \\
8,892 \\
9,021 \\
8,780 \\
7,280 \\
\end{array}$ \\
\hline $9-26-77$ & & & & & & $2.58: 1.5$ & $\$ 42,757$ \\
\hline
\end{tabular}




\section{Cyclotron Operations}

In addition to the routine maintenance of the cyclotron, the 600 ampere rectifier supplying d.c. for the ion source was replaced due to water damage. The water damage resulted from the rupture of a cooling water hose due to the malfunctioning of a backup demineralized water pump supplying the building. Replacement and testing of the rectifier required three days. Another short delay to the startup of a run was caused by the malfunctioning of the current limiter ampere meter in the bias circuit which appeared as sparking in the cyclotron tank until it was noted that the problem was due to the malfunctioning meter.

\section{FISSION PRODUCTS}

\section{Krypton-85 Enrichment Facility (R. W. Schäich)}

Five of the ${ }^{85} \mathrm{Kr}$ enrichment columns were operative during the month of September and all the units were functioning according lu design. Two colums in the south bank were unloaded during September, 1977. Expected yield on one of these colums should be $>20 \%$ enrichment in ${ }^{85} \mathrm{Kr}$. Analysis of products will be reported next month. One column in the north bank that was shut down due to an electrical overload in the chilled water compressor system was restarted. The last column in the south bank and two columns in the north bank are scheduled for unloading in October, 1977.

Cesium-137 Pilot Production (R. W. Schaich)

(Production and Inventory Accounts)

1. Process Status

The ${ }^{13 \%}$ Cs processing equipment has leen placed in etandby status.

2. Operational Summary

\section{Product Inventory}

(Decay calculated through August 31, 1977)

Inventory Material

Amount (Ci)

Cesium-137 chloride powder 30,200

Total Inventory Material 30,200 
Non-Inventory Material

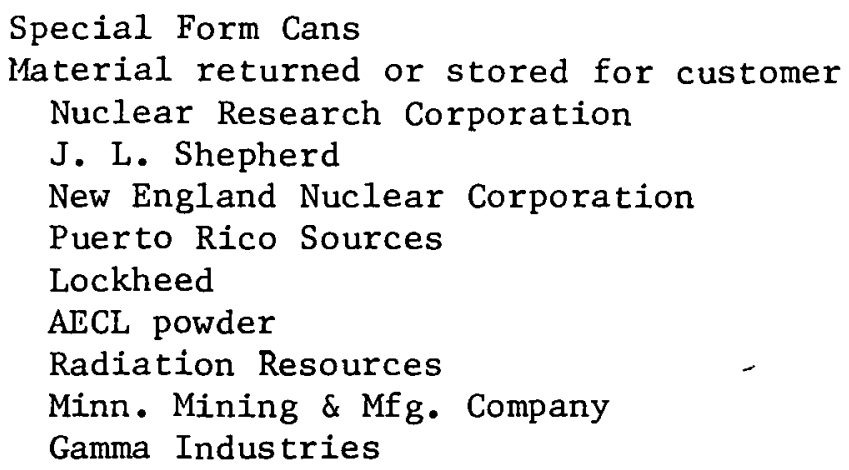

$21.7,800$

\section{Current Orders}

All orders on hand have been completed and the material placed into storage awaiting recelpt of release for the material.

Strontium-90 Pilot Production (R. W. Schaich)

(Production and Inventory Accounts)

\section{Process Status}

The generator loading of three ${ }^{90} \mathrm{Sr}$ heat sources for Sentinel-8 generators (Teledyne Energy Systems) was completed on September 2, 1977 and the units were shipped to the customer. 
Product Inventory

(Decay calculated through August 31, 1977)

Inventory Material

${ }^{90} \mathrm{Sr}$ titanate powder $( \pm 5 \%)$

Sources in fabrication

Stock powder cans

Stock solution
Amount (Ci)

0

0

3,325

200

Total Inventory Material

3,525

INon-Inventory Material

Amount (Ci)

Batch 26Er-74RE

7,900

Calorimeter Standards

Weather Buroau oource

4,800

11,400

SNAP-7B

156,300

SNAP-7C

24,600

SNAP-7D

143,000

SNAP material purchase ${ }^{a}$

248,300

AGN-4

38,400

Total Non-Inventory Material

634,700

TOTAL INVENTORY AND NON-INVENTORY MATERIAL

638,225

${ }^{a_{S}}$ trontium-90 purchased under DRRD program.

Fabrication Summary

$\frac{\text { Sept. } 1977}{\text { No. } \quad \mathrm{Ci}} \quad \frac{\mathrm{CY} 1977}{\text { No. }} \stackrel{\mathrm{Ci}}{\text { No. } 1977}$

Sources

Fabricated

$3 \quad 157,000 \quad 3 \quad 157,000$

3157,000

Shipped

3157,000

4177,000

/ 177,000

Spccial Form Cans

Fabricated

Shipped

$\begin{array}{rrrrrr}0 & 0 & 0 & 0 & 0 & 0 \\ 0 & 0 & 2 & 20 & 2 & 20\end{array}$

Short-Lived Fission Production (R. W. Schaich)

(Production and Inventory Accounts)

Isotope

Xenon-133

Zirconium/Niobium-95
Number of Batches

3

1
Amount (Ci)

2600

50 


\title{
RADIOISOTOPE SALES
}

\author{
J. E. Ratledge
}

Shipments made during the month that may be of interest are 1 isted below:

Customer

Isotope

Amount

\section{Large Quantities}

New England Nuclear Corporation Self-Powered Lighting, Ltd. American Atomics Corporation Texas Instrument, Inc. Schwarz/Mann

$\begin{array}{lr}\text { Tritium } & 8,000 \mathrm{Ci} \\ \text { Tritium } & 4,000 \mathrm{Ci} \\ \text { Tritium } & 15,000 \mathrm{Ci} \\ \text { Tritium } & 1,500 \mathrm{Ci} \\ \text { Tritium } & 1,500 \mathrm{Ci}\end{array}$

\section{Items Used in Cooperative. Programs}

University of Kentucky University of Southern California
Platinum-195m

P1atinum-195m $\sim 40 \mathrm{mCi}$ $10 \mathrm{mCi}$

The radioisotope sales and shipments for October 1975 through September 1976 and the 12 months of fiscal year 1977 are given in Table 2 .

Table 2. Radioisotope Sales and Shipments

\begin{tabular}{|c|c|c|}
\hline Item & $\begin{array}{c}10-1-75 \text { thru } \\
9-30-76\end{array}$ & $\begin{array}{c}10-1-76 \text { thru } \\
9-30-77\end{array}$ \\
\hline $\begin{array}{l}\text { Inventory items } \\
\text { Major products } \\
\text { Radioicotope services } \\
\text { Cyclotron irradlations } \\
\text { Miscellaneous processed materials } \\
\text { Packing and Shipping }\end{array}$ & $\begin{array}{r}351,386 \\
54,386 \\
163,469 \\
207,289 \\
48,590 \\
111,817 \\
\end{array}$ & $\begin{array}{l}479,800 \\
109,847 \\
250,386 \\
314,222 \\
102,485 \\
194,584\end{array}$ \\
\hline Total & 936,937 & $\$ 1,451,324$ \\
\hline Number of shipments & 2,133 & 2,438 \\
\hline
\end{tabular}

PUBLICATIONS

REPORTS

E. Lamb, Radioisotope Distribution Program Progress Report for August 1977, ORNL/TM-6080, Oak Ridge National Laboratory (September 1977). 
THIS PAGE

\section{WAS INTENTIONALLY \\ LEFT BLANK}


ORNL/TM-6154

INTERNAL DISTRIBUTION

1. F. N. Case

2. W. R. Casto

3. J. A. Cox

4. R. F. Hibbs

5. E. Lamb

6. H. H. Nichol

7. C. L. Ottinger

8. J. K. Poggenburg

9. H. Postma
10. M. E. Ramsey

11. J. E. Ratledge

12. C. R. Richmond

13. R. W. Schaich

14. M. R. Skidmore

15. M. J. Skinner

16-17. Central Research Library

18-19. Laboratory Records Department

20. Laboratory Records - RC

21. Document Reference Section

\section{EXTERNAL DISTRIBUTION}

22. B. J. Dropesky, LASL, Los Alamos, New Mexico

23-24. J. H. Jarrett, PNL, Richland Washington

25. D. K. Jones, Richland Operations Office, Richland, Washington

26. J. N. Maddox, DOE-DBER, Washington, D.C.

27. H. A. O'Brien, LASL, Los Alamos, New Mexico

28. F. J. Skozen (Krizek), Argonne Cancer Research Hospital, Chicago

29. L. G. Stang, Jr., BNL, New York

30. W. H. Weyzen, DOE-DBER, Washington, D.C.

31-32. R. W. Wood, DOE-DBER, Washington, D.C.

33. Donner Laboratory Library, Univ, of California, Berkeley, Calif., 94720

34. Research and Technical Support Division, ORO

35-36. Technical Information Center 